\title{
CHRISTIAN ORSENIGO
}

\section{A Newly Identified Relief from the Tomb-Chapel of Mose at Saqqara}

\author{
Hierzu Tafel XXV-XXVI
}

Twenty years ago, Jaromír Málek wrote in a review article of Gaballa's publication of the tomb-chapel of Mose, scribe of the Treasury of Ptah under Ramesses II, that 'sections of the decorated walls of Mose's chapel must have either been destroyed or, unrecognized, still await identification'. This is no longer the case of the relief here presented.

I have recently published an article on the tomb-chapel of Mose ${ }^{2}$, based on the archival documentation left by Victor Loret following his discovery in November 1898 of the official's tomb in Saqqara. These records, mostly preserved in the Egyptological Archives of the Università degli Studi di Milano ${ }^{4}$, are part of the rich documentation that was collected by the French

\footnotetext{
I am deeply grateful to Stephen Quirke for having corrected my English. Also I must express here my sincere gratitude to Elmar W. Seibel, president of Ars Libri Ltd., Boston, and Mr. Lucien Viola for their valuable help with my search.

J. Málek, 'Two problems connected with New Kingdom tombs in the Memphite area', JEA 67 (1981), 163.

${ }^{2}$ P. Piacentini/C. Orsenigo, 'The discovery of the tomb of Mose and its «juridical inscription», in P. Piacentini/C. Orsenigo (eds.), Egyptian Archives. Proceedings of the First Session of the International Congress Egyptian Archives/Egyptological Archives, Milano, September 9-10, 2008 (Quaderni di Acme 111; Milano, 2009), 83-102.

${ }^{3} \mathrm{PM} \mathrm{III}^{2} / 2$, 553-555. Loret located the tombchapel of Mose on 29 November 1898, and assigned it the number 5. For the numbering of the tomb and its location, see V. Loret, 'Fouilles dans la Nécropole Memphite (1897-1899)', BIE 10, III Sér. (1899), 95-96, and the plan following p. 100.

${ }^{4}$ Piacentini/Orsenigo, in Piacentini/Orsenigo (eds.), Egyptian Archives, 84.
}

scholar during his excavations in the area North of the pyramid of Teti from 1897 to $1899^{5}$.

Among Loret's documentation relating to the tomb-chapel of Mose, I have found the photograph of a relief lying still in situ that does not appear in the publication of the tomb by Gaballa Aly Gaballa in which he collected all the identified blocks known to him so far (Taf. XXV, Abb. 1) $)^{7}$.

Gaballa also used for his monograph Battiscombe Gunn's documentation relating to the tomb-chapel of Mose which is kept at the Griffith Institute. This includes notes and drawings of the blocks, which were still scattered in situ, and were made by the British archaeologist while working in Saqqara for the Antiquities

P. Piacentini, 'Saqqarah, 15 août 1897-12 février 1899. Les journaux de fouilles et autres documents inédits de Victor Loret', Aegyptus 84 (2004), 3-20; P. Piacentini (ed.), Victor Loret in Egypt (1881-1899). From the Archives of the Milan University to the Egyptian Museum in Cairo (Cairo, 2008), 11-14 and cat. no. 18-25. Some other documents from the Egyptological Archives of Milan relating to Loret's excavations in Saqqara are reproduced in P. Piacentini (ed.), Egypt and the Pharaohs. From the Sand to the Library. Pharaonic Egypt in the Archives and Libraries of the Università degli Studi di Milano (Le vetrine del sapere 9; Ginevra-Milano, 2010), 18-19, $23,78-79$.

The photograph has been reproduced for the first time in Piacentini/Orsenigo, in Piacentini/Orsenigo (eds.), Egyptian Archives, 101 Fig. $6 a$.

G. A. Gaballa, The Memphite Tomb-Chapel of Mose (Warminster, 1977). While finishing this brief contribution I heard news of the death of Prof. Dr. Gaballa Aly Gaballa, to whom we still owe the fundamental study on the tomb-chapel of Mose. 
Service $^{8}$. It is therefore highly likely that the relief here presented disappeared in the time span between Loret's excavations and the activities of Gunn in the area.

The tomb-chapel of Mose suffered from the long-term exploitation of the Memphite necropolis during the period preceding the exploration by Loret ${ }^{9}$, but also afterwards ${ }^{10}$. Certainly, some reliefs had been left in situ as proven by the fact that, at the end of the 1990s, when a mission of the Supreme Council of Antiquities, led by Zahi Hawass, succeeded in relocating the tomb-chapel of Mose ${ }^{11}$, eleven limestone blocks

${ }^{8}$ Gaballa, Mose, 2. Gunn worked for the Antiquities Service in Saqqara during the early twenties of the last century; see M. L. Bierbrier, Who was who in Egyptology, $4^{\text {th }}$ rev. edn. (London, 2012), 232; S. E1Fikey, The tomb of the vizier Re'-wer at Saqqara (Egyptology Today 4; Warminster, 1980), 2. For more information on Gunn's records in the Griffith Institute, see www.griffith.ox.ac.uk/gri/4gunn.html accessed 23.04.2012.

Some reliefs belonging to the tomb-chapel of Mose appeared on the antiquities market long before Loret's excavations such as some inscribed blocks from the tomb pillars that Sir Charles Nicholson bought, in 1862, from Hanna Massara, the dragoman of the British Consulate. They are now kept in the Nicholson $\mathrm{Mu}-$ seum of Sydney University (R1131-1135): $\mathrm{PM} \mathrm{III}^{2} / 2$, 554; Gaballa, Mose, 18-19, pls 41-44; more recent bibliography on these blocks, K. N. Sowada, 'Sir Charles Nicholson: an early Scholar-Traveller in Egypt', in K. N. Sowada/B. G. Ockinga (eds), Egyptian Art in the Nicholson Museum, Sydney (Sydney, 2006), 5, and in particular 11 n. 40. Málek, JEA 67 (1981), 163 n. 27 - following A. Nibbi, 'A note on the Egyptian Collection in the Nicholson Museum', GM 27 (1978), 8 - pointed out that the upper part of pillar II (Nicholson B) reproduced in Gaballa, Mose, pl. 42, apparently is not in the Nicholson Museum.

${ }^{10}$ There is a fragmentary relief showing Mose worshipping Isis among the blocks that surely left Egypt after the Loret excavations, which is now in the Museum of Fine Arts, Boston (1974.315): $\mathrm{PM} \mathrm{III}^{2} / 2$, 555; Gaballa, Mose, 15, pl. 30a; add to bibliography G. T. Martin, Corpus of Reliefs of the New Kingdom from the Memphite Necropolis and Lower Egypt, I (London, 1987), 33 no. 80; see also MFA Boston database www.mfa.org/search/mfa/1974.315 accessed 23.04.2012. Two other blocks are kept in the Museum August Kestner, Hannover (1935.200.190-191): see appendix at the end of this article for bibliography.

J. Leclant/A. Minault-Gout, 'Fouilles et travaux en Égypte et au Soudan, 1997-1998', Orientalia 68 (1999), 351 (called incorrectly Ptahmès); Z. Hawass, 'Excavating the Old Kingdom: The Egyptian had been recovered as well as part of a tomb pillar $^{12}$.

While publishing the article on the tombchapel of Mose I also planned a more detailed study of the relief presented here with the main purpose of identifying its current location ${ }^{13}$.

The relief, very probably part of a limestone wall of the tomb (see below), is decorated with an offering scene carved in sunk relief, for which it is possible to make out a lost upper register. The left hand portion shows the sacred bull Apis striding right on a high podium within a shrine. A lotus-shaped offering vase lies at his feet $^{14}$. Above the bull, an inscription is carved that can be read as:

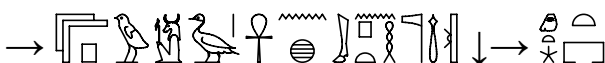 Hp ${ }^{c}$ h $h$ whm n Pth ntr ${ }^{c} 3$ hntj dw3t}

The living Apis ${ }^{15}$, herald of $\mathrm{Ptah}^{16}$, the great god, foremost of the Duat

Archaeologists', in Egyptian Art in the Age of the Pyramids (New York, 1999), 165 n. 21; Z. Hawass, Secrets from the Sand: My search for Egypt's past (Cairo, 2003), 140, 154-155.

${ }^{12}$ We can assume that these are the eleven blocks of the south wall of the open court which contained part of the 'juridical' inscription, that never reached the Egyptian Museum in Cairo, probably left in situ; see Gaballa, Mose, 2 n. 21. For a bibliography of the 'juridical' inscription of Mose see, e.g., Piacentini/ Orsenigo, in Piacentini/Orsenigo (eds.), Egyptian Archives, 91 n. 29.

${ }^{13}$ Piacentini/Orsenigo, in Piacentini/Orsenigo (eds), Egyptian Archives, 102.

${ }^{4}$ For a similar scene showing the sacred bull Apis in another tomb likewise dated to the $19^{\text {th }}$ Dynasty at Saqqara, see, e.g., S. Gohary, The twin tomb chapel of Nebnefer \& his son Mahu at Sakkara (Cairo, 2009), 23, 75 pl. 28b. On the 'chapel A' or 'Apis chapel' of the tomb of Tia and Tia, apparently connected with the cult of the Apis bull, see G. T. Martin, The hidden tombs of Memphis: new discoveries from the time of Tutankhamun and Ramesses the Great (London, 1991), 109112 and more recently G. T. Martin, The tomb of Tia and Tia: a royal monument of the Ramesside Period in the Memphite Necropolis (London, 1997), 5-6, 27-32, with bibliography.

${ }^{15}$ C. Leitz (ed.), Lexikon der ägyptischen Götter und Götterbezeichnungen, V (OLA 129; Leuven-Paris -Dudley MA 2002), 117. Please note that the sign for the god Apis is reproduced here holding the wassceptre whereas it does not appear in the original inscription. 
A male figure with shaven head, wearing a long kilt with a pleated front-section, stands facing the shrine. He is holding out an incense burner and a libation jug in front of an offering table. Two women and a man between them, with their hands raised in the attitude of greetings to the god, can still be seen in a procession following the first officiant. The first woman wearing the same long, transparent robes as the other female figure, holds a flower in her left hand. The procession appearing on the right hand portion of the relief is accompanied by a hieroglyphic text apparently preserved only in the first four columns. The surviving text unfortunately does not bear any name that could identify the figures depicted. It might be a representation of the owner of the tomb-chapel, Mose, in company of some members of his family such as his wife and his parents ${ }^{17}$. At the same time it cannot be excluded that the last two persons in the procession are a couple represented only once in the tomb in a banquet scene, whose family relationship with Mose is not clear ${ }^{18}$.

From the photograph it is not so easy to identify all the remaining hieroglyphic signs of the inscription above the procession. I tentatively suggest to interpret the first four columns as:

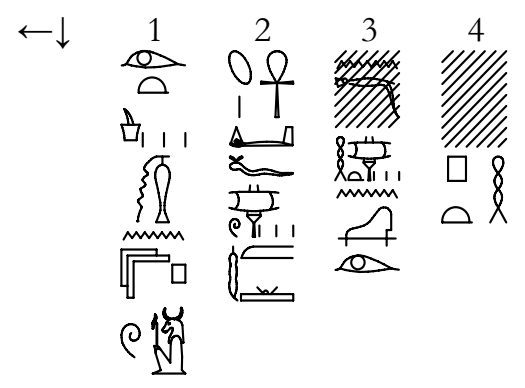

\footnotetext{
${ }^{16}$ Ibid., II, 521. See also, e.g., D. Devauchelle, 'Une invocation aux dieux du Sérapéum de Memphis', in W. Clarysse, A. Schoors and H. Willems (eds.), Egyptian Religion: The Last Thousand Years. Studies dedicated to the memory of Jan Quaegebeur, I (OLA 84; Leuven, 1998), 593.

${ }^{17}$ From the scenes and the inscriptions of his tombchapel, it emerges that the immediate family of Mose was composed of his father Huy, his mother Nubnefret, his wife Mutnefret, five or six children and one grandson; see Gaballa, Mose, 28-29, 32 (family tree).

${ }^{18} \mathrm{Gab} a l l a$, Mose, 29. On the aforementioned banquet scene, see appendix at the end of this article and Taf. XXV, Abb. 2.
}

(1) jrt sntr qbh $n$ Hp (2) ${ }^{c} n \underline{h} d=f \underline{t} 3 w$ n $n \underline{d m}$ (3) [ $n$ m] hyt $n$ Wsjr (4) [š̌ pr-had $n$ ?] Pth

The performing of censing and libation to the living Apis ${ }^{19}$, that he may give the sweet north wind to the Osiris, [scribe of the Treasury of ?] Ptah.

The photograph that has been found in Loret's Archives is labeled in his own hand on the verso: "Stèle tombée sur le sol",20. Loret, in his article on the 'juridical' inscription of Mose, names the first of the two remaining rooms of the tomb-chapel "la salle à la stele", even though no stela was reported to have been found $^{22}$. Most probably Loret was referring to the block here presented. According to the plan of Gaballa emended by Málek, it can be assumed that the relief was part of a wall of 'room I', or 'main cult chapel', probably the Western one ${ }^{23}$.

As mentioned above, I have focused my attention mainly on identifying the current location of the relief. After presenting my inquiry to colleagues and curators of museum collections, Geoffrey T. Martin found in his archive of New Kingdom Memphite reliefs a photograph showing part of the block - the left hand portion which shows the Apis bull in his shrine, two columns of text - the second one partly broken away -, the arms with the censer and the libation vessel of the first men, and the offering table below $^{24}$. The right edge of the relief appears in the photograph very jagged and a visible crack runs through the figure of the shrine and the bull. It can be assumed that the block broke into two when it was taken from the tomb wall.

The back of the photograph is annotated with measurements and a brief description: "Bas

\footnotetext{
${ }^{19}$ See above, note 15.

${ }^{20}$ Piacentini/Orsenigo, in Piacentini/Orsenigo (eds.), Egyptian Archives, 101 Fig. 6b.

${ }^{21}$ V. Loret, 'La grande inscription de Mes à Saqqarah', Z̈̈S 39 (1901), 1.

${ }_{22}$ Gaballa, Mose, 3: "On the West wall Loret considered that there may have been a stela. But of that wall nothing has recognisably survived except a tiny fragment recorded by Gunn." See Gaballa, Mose, 9, pl. $13 \mathrm{c}$.

${ }^{23}$ For the location of 'room I' inside the tombchapel see the plan published in Gaballa, Mose, pl. 1 and that by Málek, JEA 67 (1981), 161.

${ }^{24}$ I am deeply grateful to Prof. Geoffrey T. Martin for having provided me with this information.
} 
relief en calcaire representant le boeuf Apis de la XIX ${ }^{\text {eme }}$ dynastie environ 1300 av J.-C. en 2 morceaux". In addition, there is a stamped name and address of the person whom I afterwards identified as the owner of the piece, Mr. Robert Viola.

After many attempts I succeeded in contacting the son of the late Robert Viola, Mr. Lucien Viola, who remembers having seen the relief actually the left half portion - during his childhood in New York at his father's art gallery ${ }^{25}$. He didn't recall having seen with his father other adjoining fragments as shown in the photograph by Loret but he provided me with the information that the block had previously belonged to Maurice Nahman, the world famous Egyptian art dealer based in Cairo, who, moreover, was his grandfather ${ }^{26}$. In addition, Mr. Viola gave me the date on which his father consigned the relief for sale to Sotheby's New York: May 16, $1980^{27}$. The block appears in the catalogue sale as lot 319 and is attributed in the description to Khaemwaset, probably because of the presence of the sacred bull Apis. Thanks to Victor Loret's documents it is now certain that this attribution has to be rejected.

The relief is today kept at the Rosicrucian Egyptian Museum of San Jose, where it was probably accessioned following the sale at Sotheby's (Taf. XXVI, Abb. 3$)^{28}$. The location of

\footnotetext{
${ }^{25}$ Lucien Viola, renowned art collector and dealer in ancient and contemporary art, owned and directed L'Ibis Gallery Ltd. in New York until the early 1990's. For more information see, e.g., www.galeriere.com/eng/lucienviola-eng.swf.

${ }_{26}$ Bierbrier, Who was who, 397. See also R. Pintaudi, 'Documenti per una storia della papirologia in Italia', AnPap 5 (1993), 156-170, with amazing photographs of Nahman's antiquities gallery in Cairo on pp. 167 and 169.

${ }^{27}$ Sotheby Parke Bernet Inc. (New York) Sale Cat. May 16, 1980, no. 319.

${ }^{28}$ PM VIII/5, www.griffith.ox.ac.uk/gri/8rel100.pdf (working file, May 30, 2011), 67 no. 804-055-355. We have signaled the identification of the block to the Griffith Institute, Oxford, in May 2012. A good photograph of the relief as displayed in the Rosicrucian Egyptian Museum, San Jose, can be found at: www.flickr.com/photos/mharrsch/316503863/in/set72157594303869444. I am indebted to Mrs Mary Harrsch for this information. I was unable to contact
}

the other portion of the relief - the right one appearing in Loret's photograph - remains an open question, one that I hope to solve in the future.

\section{Appendix}

I take the opportunity of this article to reproduce in the accompanying plates another photograph likewise found in the Archives of Victor Loret preserved in Milan (Taf. XXV, Abb. 2), whose original glass-plate is kept at the University of Lyon ${ }^{29}$. A similar - or possibly the same - print has been reproduced in the monograph of Gaballa but due to lack of consistency in the quality many details do not appear $^{30}$. Gaballa asserts that the original photograph, once in possession of Rudolf Anthes, was destroyed during World War II and the one he reproduced was a print provided by Steffen Wenig on behalf of the Egyptian Department of the former Staatliche Museen zu Berlin ${ }^{31}$.

The photograph shows the right-hand northern interior wall of 'room I' (see above) at the time of Loret's excavation. Today the wall no longer exists, but portions of it are preserved in the Egyptian Museum in Cairo ${ }^{32}$ and in the Museum August Kestner, Hannover ${ }^{33}$.

the person in charge of the collection of the Rosicrucian Egyptian Museum; therefore, I am not able to provide any inventory number for the relief.

${ }^{29}$ Lyon, Me-16 (inventory number S. 91). A print from this glass plate is reproduced small size and low resolution, in F. Buyer, 'Les plaques photographiques de Lyon, témoins de l'activité archéologique de Victor Loret à Saqqara', KYPHI 5 (2006), 24 pl. 7c.

${ }^{30}$ Gaballa, Mose, pl. 11.

${ }^{31}$ Gaballa, Mose, 35 n. 1. See also R. Anthes, 'Das Bild einer Gerichtsverhandlung und das Grab des Mes aus Sakkara', MDAIK 9 (1940), 105-109, pl. 18.

${ }^{32}$ Egyptian Museum, Cairo: TR. 22.5.25.1. PM $\mathrm{III}^{2} / 2,554$ (16); Gaballa, Mose, 8, pl. 13.

3 Museum August Kestner, Hannover: 1935.200.190-191. PM III'2/2, 554 (for the block 1935.200.191); Gaballa, Mose, 8-9, pls 11-12; now add to bibliography: Martin, Corpus of Reliefs of the New Kingdom, 32, no. 79; R. Drenkhahn, Ägyptische Reliefs im Kestner-Museum Hannover: 100 Jahre Kestner-Museum Hannover 1889-1989, (Hannover, 1989), 120-124, cat. no. 40/41. I am grateful to Christian E. Loeben, Keeper of Egyptian Antiquities at the Museum August Kestner for having shared with me much information on the blocks. On their provenance from the collection of Friedrich von Bissing, see Piacentini/Orsenigo, in Piacentini/Orsenigo (eds.), Egyptian Archives, 100 and 102. 


\section{Summary}

A photograph has recently been found among the records left by Victor Loret following his discovery in 1898 of the tomb-chapel of Mose at Saqqara, of a relief lying still in situ, that does not appear in the publication of the tomb by Gaballa. The relief, very probably part of a limestone wall, is decorated with an offering scene showing a man, accompanied by a little procession, censing and libating before the
Apis-bull in a shrine. The paper retraces the path of the relief from the art gallery of Maurice Nahman to the current location of its remaining left hand portion at the Rosicrucian Egyptian Museum, San Jose.

\section{Keywords}

Apis - Loret, Victor - Mose - Nahman, Maurice San Jose, Rosicrucian Egyptian Museum - Saqqara 


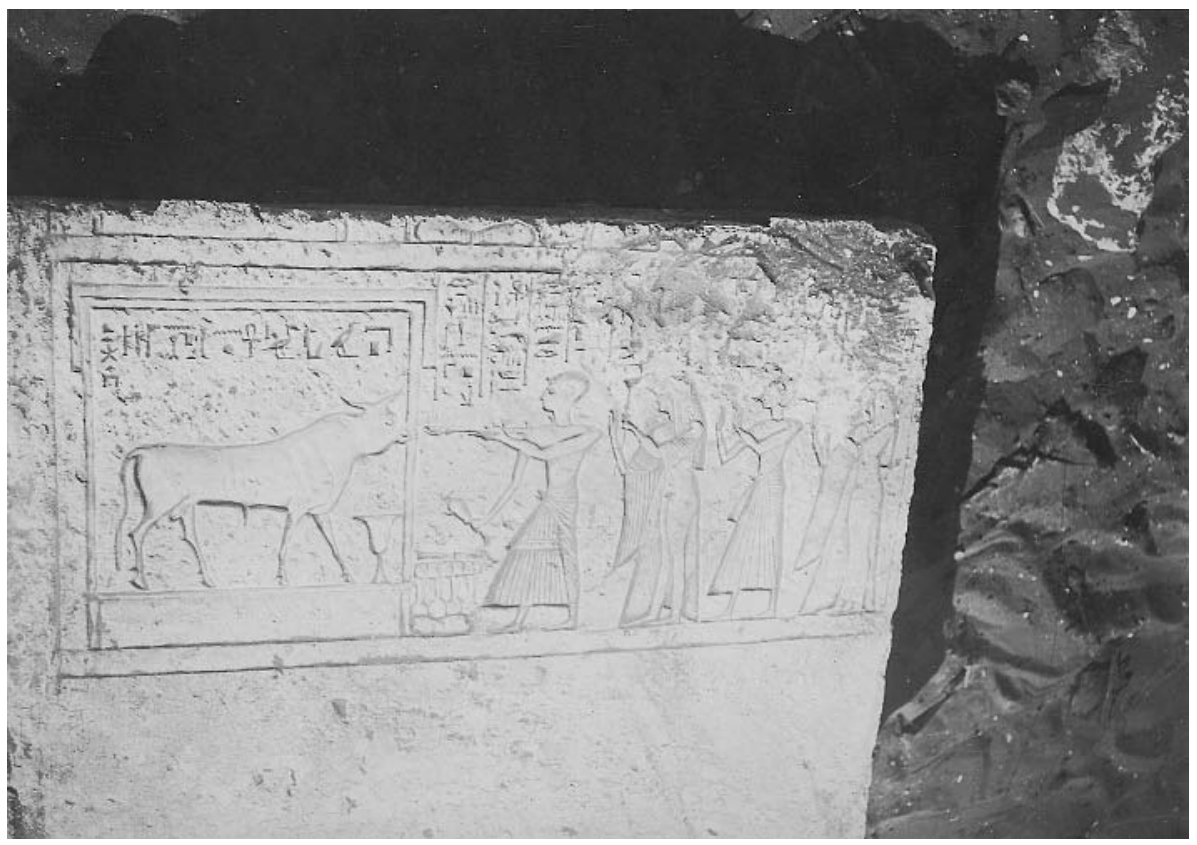

1. The relief at the time of Loret's excavation (Egyptological Archives \& Library, Università degli Studi di Milano, Victor Loret Collection) (zu Orsenigo, Relief of Mose).

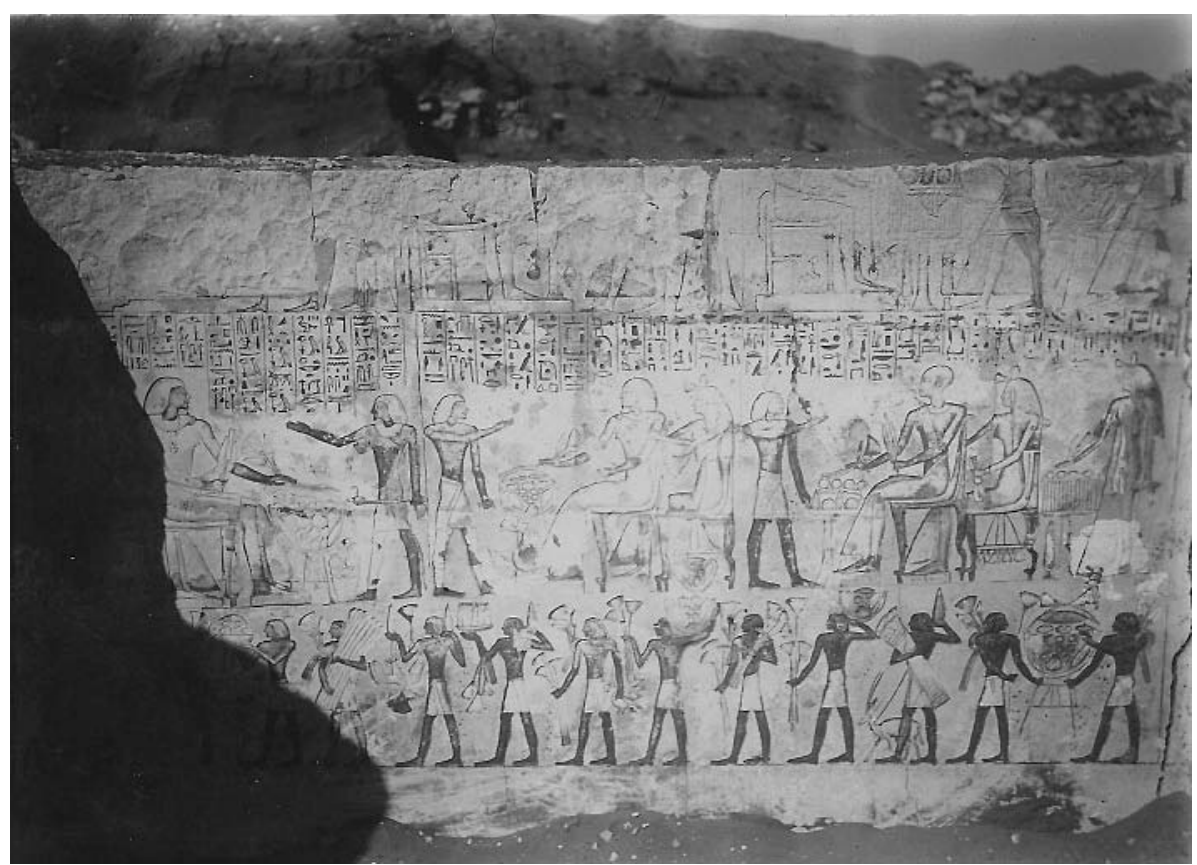

2. The right-hand northern interior wall of 'room I' at the time of Loret's excavation (Egyptological Archives \& Library, Università degli Studi di Milano, Victor Loret Collection) (zu Orsenigo, Relief of Mose). 


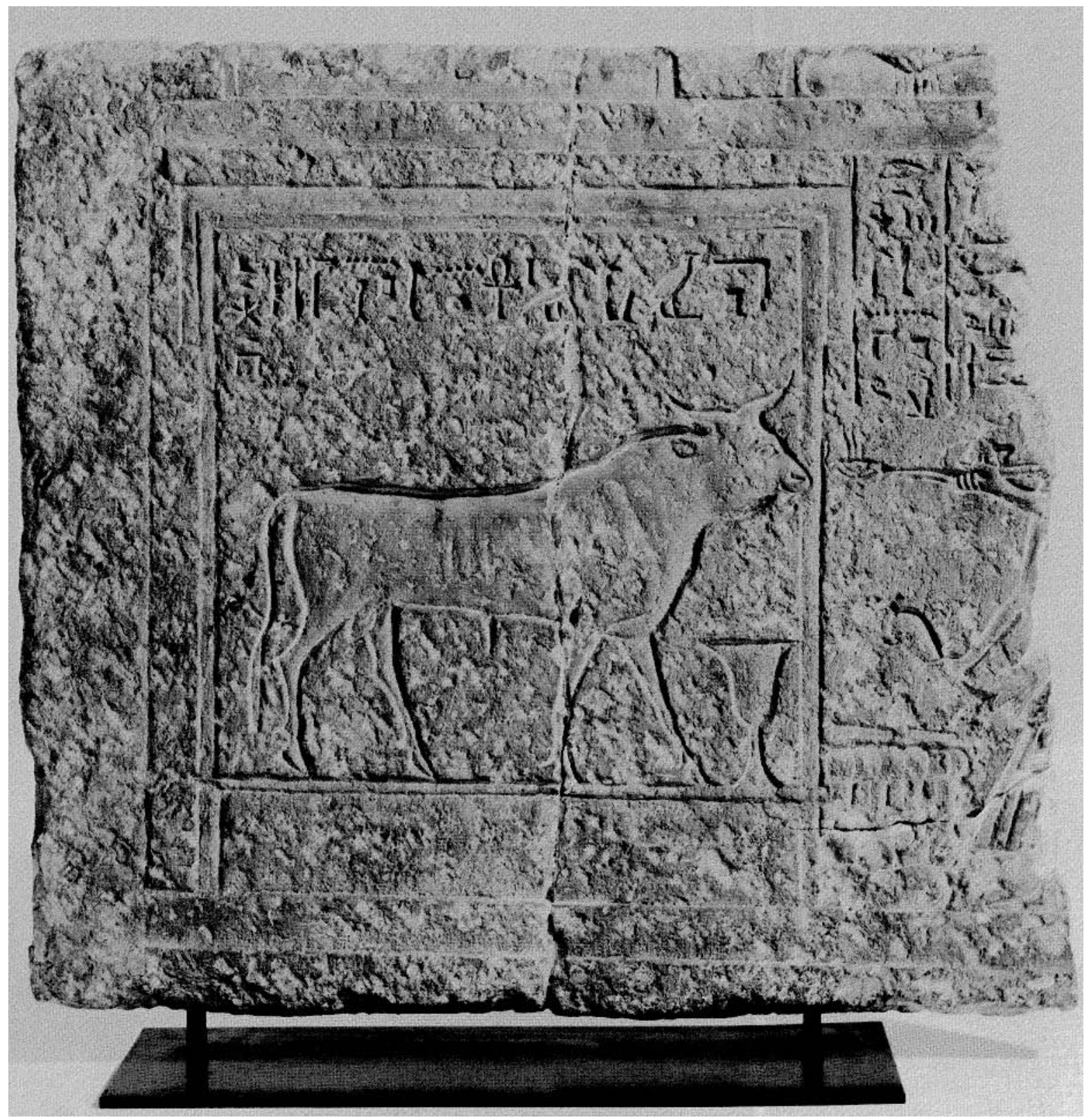

3. The portion of the relief now kept at the Rosicrucian Egyptian Museum, San Jose, CA

(Egyptological Archives \& Library, Università degli Studi di Milano, Bernard V. Bothmer Collection) (zu Orsenigo, Relief of Mose). 